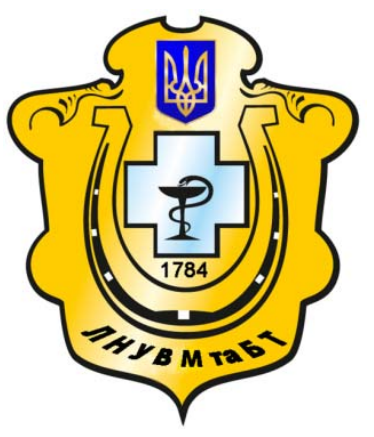

Науковий вісник Львівського національного університету ветеринарної медицини та біотехнологій імені С.3. Гжицького

Scientific Messenger of Lviv National University of Veterinary Medicine and Biotechnologies named after S.Z. Gzhytskyj

doi:10.15421/nvlvet7044

ISSN 2413-5550 print

ISSN 2518-1327 online

$\underline{\text { http://nvlvet.com.ua/ }}$

УДК 619:616.61:636.7:616-076

\title{
Клінічна ефективність препарату, що містить глюкозаміну гідрохлорид, у лікуванні сечокам'яної хвороби домашніх котів
}

\author{
Д.В. Морозенко ${ }^{1}$, К.В. Глєбова ${ }^{2}$ \\ d.moroz.vet@gmail.com, katerinaglebova25@gmail.com \\ ${ }^{1}$ ДУ «Інститут патології хребта та суглобів ім. проф. М.І. Ситенка Начіональної академї медичних наук \\ Украӥни», вул. Пушкінська, 80, м. Харків, 61024, Украӥна; \\ ${ }^{2}$ Національний фармацевтичний університет, \\ вул. Пушкінська, 53, м. Харків, 61002, Украӥна
}

\begin{abstract}
У статті розглянуто питання ефективності лікування домашніх котів із сечокам'яною хворобою, яким у схемі терапевтичних заходів було застосовано препарат, щзо містить глюкозаміну гідрохлорид (Урі-ізі). За результатами досліджень було встановлено, щзо схема лікування із застосуванням препарату Урі-ізі, щзо містить глюкозаміну гідрохлорид, сприяє більш швидкому клінічному одужанню тварин, а також розчиненню кристалів трипельфосфату кальцію і підвищенню концентрачії глікозаміногліканів у сечі. Це підтверджується тим, що на 14 день лікування у тварин у другій групі із застосуванням глюкозаміну гідрохлориду кониентрачія глікозаміногліканів в сечі була нижче на 12,3\%, ніж у здорових котів, при иьвому в осаді сечі зустрічалися лише поодинокі кристали трипельфосфату кальцію. У першій групі вміст глікозаміногліканів у сечі на 14 день було на 62,6\% нижче, ніж у клінічно здорових котів, при иьому в осаді зберігалася помірна кількість кристалів трипельфосфату кальиію. При иььому в другій групі конщентрація глікозаміногліканів на 14 день було наближена до норми, оскільки у сечі спостерігалися лише поодинокі кристали. Таким чином, можна сказати, що введення в схему лікування препарату, що містить глюкозаміну гідрохлорид, дозволяє прискорити одужання котів з сечокам'яною хворобою, шео підтверджується даними лабораторних досліджень. Це дозволяє рекомендувати препарат Урі-ізі для проведення комплексного лікування домашніх котів, хворих на струвітний уролітіаз.

Ключові слова: уролітіаз, коти, глюкозаміну гідрохлорид, сеча, трипельфосфат кальцію, синулокс, спазмобрю, канефрон, катозал, урі-ізі, лікувальна дієта.
\end{abstract}

\section{Клиническая эффективность препарата, содержащего глюкозамина гидрохлорид, в лечении мочекаменной болезни домашних кошек}

\author{
Д.В. Морозенко ${ }^{1}$ Е.В. Глебова ${ }^{2}$ \\ d.moroz.vet@gmail.com, katerinaglebova25@gmail.com
}

${ }^{I}$ ГУ «Институт патологии позвоночника и суставов им. проф. М.И. Ситенко Национальной академии медицинских наук Украиныл, ул. Пушкинская, 80, г. Харьков, 61024, Украина,

${ }^{2}$ Национальний фармацевтический университет,

ул. Пушкинская, 53, г.. Харьков, 61002, Украина

\begin{abstract}
В статье рассмотрен вопрос эффективности лечения домашних кошек с мочекаменной болезнью, которым в схеме терапевтических мероприятий был применен препарат, содержащий глюкозамина гидрохлорид (Ури-изи). По результатам исследований было установлено, что схема лечения с применением препарата Ури-изи, содержащего глюкозамина гидрохлорид, способствует более быстрому клиническому выздоровлению животных, а также растворению кристаллов трипельфосфата кальция и повышению концентрации гликозаминогликанов в моче. Это подтверждается тем, что на 14 день лечения у животных во второй группе с применением глюкозамина гидрохлорида конщентрация гликозаминогликанов в
\end{abstract}

\section{Citation:}

Morozenko, D.V., Glebova, E.V. (2016). Clinical efficacy of a preparation containing glucosamine hydrochloride, in the treatment of urolithiasis of domestic cats. Scientific Messenger LNUVMBT named after S.Z. Gzhytskyj, 18, 3(70), 184-186. 
моче была ниже на 12,3\%, чем у здоровых кошек, при этом в осадке мочи встречались лишь единичные кристалль трипельфосфата кальция. В первой группе содержание гликозаминогликанов в моче на 14 день было на $62,6 \%$ ниже, чем у клинически здоровых кошек, при этом в осадке сохранялось умеренное количество кристаллов трипельфосфата кальция. При этом во второй группе концентрация гликозаминогликанов на 14 день было приближено к норме, а в моче наблюдались лишь единичные кристалль. Таким образом, можно сказать, что введение в схему лечения препарата, содержащего глюкозамина гидрохлорид, позволяет ускорить выздоровление котов с мочекаменной болезнью, что подтверждается данными лабораторных исследований. Это позволяет рекомендовать препарат Ури-изи для проведения комплексного лечения домашних кошек, больных струвитным уролитиазом.

Ключевые слова: уролитиаз, кошки, глюкозамина гидрохлорид, моча, трипельфосфат кальция, синулокс, спазмобрю, канефрон, катозал, ури-изи, лечебная диета.

\title{
Clinical efficacy of a preparation containing glucosamine hydrochloride, in the treatment of urolithiasis of domestic cats
}

\author{
D.V. Morozenko ${ }^{1}$, E.V. Glebova ${ }^{2}$ \\ d.moroz.vet@gmail.com; katerinaglebova25@gmail.com
}

\author{
${ }^{I}$ Institute of Spine and Joint Pathology. prof. M.I. Sytenko National Academy of Medical Sciences of Ukraine, \\ Pushkin Str., 80, Kharkiv, 61024, Ukraine; \\ ${ }^{2}$ National University of Pharmacy, \\ Pushkin Str., 53, Kharkiv, 61002, Ukraine
}

\begin{abstract}
In the article the question of the effectiveness of treatment of domestic cats with urolithiasis which a preparation containing glucosamine hydrochloride was used in the scheme of therapeutic interventions (Uri-Easy). According to the research, it was found that the treatment regimen with the use of drug Uri-Easy containing glucosamine hydrochloride, promotes more rapid clinical recovery of the animals, as well as the dissolution of crystals of calcium tripelfosfat glycosaminoglycans and increasing concentration in urine. This is confirmed by the fact that the 14 day treatment the animals in the second group with glucosamine hydrochloride concentration glycosaminoglycan in urine was lower by $12.3 \%$ than that in healthy cats with only single crystals of calcium tripelfosfat encountered in urine sediment. In the first group of glycosaminoglycans content in urine on day 14 were $62.6 \%$ lower than the clinically healthy cats, the precipitate thus maintained a moderate amount of calcium tripelfosfat crystals. In this second group of glycosaminoglycan concentration on the 14th day it was closer to normal, and only a few crystals were observed in urine. Thus, we can say that the introduction to the treatment regimen of the drug containing glucosamine hydrochloride, to accelerate healing cats with urolithiasis, which is confirmed by laboratory tests. This allows us to recommend the drug Uri-Easy for the comprehensive treatment of domestic cats suffering from struvite urolithiasis.

Key words: urolithiasis, cats, glucosamine hydrochloride, urine calcium tripelfosfat, synulox, spasmobru, kanefron, katozal, UriEasy, therapeutic diet.
\end{abstract}

\section{Вступ}

Сечокам'яна хвороба є однією з найбільш поширених патологій сечовивідної системи у домашніх кішок. Лікування даного захворювання засноване на застосуванні спазмолітичних засобів, рослинних нефропротекторов, а також спеціальної дієтотерапії (Aljaev et al., 2000; Chandleret al., 2002). За даними Г.О. Ющенко (Jushhenko, 2005), одним 3 основних патогенетичних ланок сечокам'яної хвороби є зниження концентрації в сечі глікозаміногліканів (ГАГ), що призводить до утворення кристалів та розвитку дизурії. Тому одним з необхідних елементів терапії уролітіазу можна вважати застосування препаратів, що містять ГАГ для корекції утворення кристалів, відновлення стінки сечовивідних шляхів, покращення клінічного стану тварин і профілактики рецидивів хвороби (Worcester, 1996; Gunn-Moore and Shenoy, 2004).

Мета $і$ завдання дослідження - провести оцінку клінічної ефективності препарату, який містить глюкозаміну гідрохлорид, у лікуванні сечокам'яної хвороби домашніх котів. Для цього було сформовано дві групи домашніх котів, хворих на струвітний уролітіаз. У другій групі тварин додатково застосовували препарат урі-ізі. Оцінку ефективності лікування прово- дили на основі клінічних даних та результатів дослідження сечі.

\section{Матеріал і методи досліджень}

Матеріалом для проведення досліджень були домашні кішки різного віку, хворі на сечокам'яну хворобу $(\mathrm{n}=20)$. У схему лікування 10 кішок був включений препарат, що містить глюкозаміну гідрохлорид, у решти 10 тварин в схему лікування даний препарат не включався. В якості контрольної групи використовували здорових кішок $(\mathrm{n}=10)$. У схему лікування включали такі препарати: Спазмобрю (скополаміну бутілбромід) - по 0,1 мл/кг підшкірно 2 рази на день 5 днів, Канефрон (трава золототисячнику, корінь любистку звичайного, листя розмарину) - по $1 / 2$ таблетки 2 рази на день - 30 днів, катозал (бутофосфан, ціанокобаламін) - по 0,2 мл / кг 1 раз в день - 7 днів, синулокс (амоксицилін, клавулановая кислота) - 12,5 мг/кг перорально 2 рази в день - 14 днів; дієтотерапія (корм Royal Canin Urinary згідно рекомендованого виробником дозування - 30 днів). Як препарат, що містить глюкозаміну гідрохлорид, застосовували капсули Урі-ізі (глюкозаміну гідрохлорид, екстракт журавлини, метілсульфонілметан, лізин) - по 1 капсулі 2 рази на день 14 днів). Контрольні дослідження сечі прово- 
дилися через 7 і через 14 днів після початку лікування (Morozenko and Tymoshenko, 2012).

\section{Результати та їх обговорення}

При первинному клінічному дослідженні у тварин спостерігалися наступні симптоми: пригнічення, зниження апетиту, а також розлади сечовипускання полакіурія, дизурія та ішурія. Для підтвердження діагнозу i оцінки ефективності проведеної терапії крім клінічного дослідження сечі визначалася концентрація ГАГ в сечі при первинному надходженні, а також через 7 i 14 днів після початку лікувальних заходів. У першій групі тварин, які не отримували в схемі лікування препарат Урі-ізі, відносна щільність сечі через 14 днів після початку лікування знизилася на $12 \%$ в порівнянні з показником до початку лікування (до початку лікування $-1,038 \pm 0,004$, через 14 днів $-1,026 \pm 0,002, \mathrm{p}<0,001)$. Рівень $\mathrm{pH}$ сечі кішок на 14 день проведення лікувальних заходів не змінився (до початку лікування - 7,20 $\pm 0,20$, через 14 днів $7,10 \pm 0,07)$. Вміст білка в сечі знижувався поступово в процесі лікування від 3,80 $\pm 0,61$ (до початку лікування) до 0,28 $\pm 0,09$ г/л (через 14 днів після лікування). Гематурія на початку лікування становила більше 30 еритроцитів у полі зору, до 14-го дня лікування склала лише 0 - 5 еритроцитів у полі зору. Показник загальних ГАГ сечі до початку лікування становив $30,10 \pm 4,21$ Од. (У контрольній групі - 121,60 \pm 2,10 Од., $\mathrm{n}=10$ ), через 7 днів - 40,30 $\pm 3,74$ Од., через 14 днів - 74,60 土 3,04 Од. При цьому кількість кристалів трипельфосфатов кальцію становило все поле зору, через 7 і 14 днів в поле зору спостерігалася помірна кількість кристалів.

У другій групі тварин, які отримували препарат Урі-ізі, що містить глюкозаміну гідрохлорид, відносна щільність сечі через 14 днів після початку лікування знизилася на $12 \%$ в порівнянні з показником до початку лікування (з 1,035 $\pm 0,003$ до $1,020 \pm 0,001$, $\mathrm{p}<0,001)$. Рівень $\mathrm{pH}$ сечі кішок до 14-го дня проведення лікувальних заходів знизився на 16\% (до початку лікування $-7,30 \pm 0,15$, через 14 днів $-6,30 \pm 0,07$; $\mathrm{p}<0,001)$. Вміст білка в сечі знижувався поступово в процесі лікування від 3,26 \pm 0,71 (до початку лікування) до 0,15 \pm 0,05 г/л (через 14 днів після лікування). Гематурія на початку лікування становила більше 30 еритроцитів у полі зору, до 14-го дня лікування припинилася. Показник загальних ГАГ сечі до початку лікування становив 25,90 $\pm 1,40$ Од. (у контрольній групі - 121,60 $\pm 2,10$ Од., $\mathrm{n}=10$ ), через 7 днів $49,10 \pm 3,21$ Од., через 14 днів - 108,30 \pm 3,93 Од. При цьому кількість кристалів трипельфосфату кальцію становило все поле зору, через 7 спостерігалося помірна кількість кристалів, а через 14 днів - поодинокі кристали в препараті.

\section{Висновки}

Під час досліджень встановлено, що схема лікування із застосуванням препарату Урі-ізі, що містить глюкозаміну гідрохлорид, сприяє більш швидкому розчиненню кристалів трипельфосфату кальцію i підвищення концентрації ГАГ в сечі. На 14 день лікування у тварин у другої групи концентрація ГАГ в сечі була нижче на 12,3\%, ніж у здорових кішок, при цьому в осаді сечі зустрічалися лише поодинокі кристали. У першій групі вміст ГАГ у сечі на 14 день був на $62,6 \%$ нижче, ніж у здорових котів, при цьому в осаді зберігалася помірна кількість кристалів трипельфосфату кальцію. При цьому в другій групі тварин концентрація ГАГ на 14-й день майже досягла рівня клінічно здорових котів. Таким чином, введення в схему лікування препарату, що містить глюкозаміну гідрохлорид, дозволяє прискорити одужання кішок 3 сечокам'яною хворобою.

Перспективи подальших досліджень. Планується провести дослідження механізмів діє глюкозаміну гідрохлориду на нирки та сечові шляхи домашніх котів при інших урологічних та нефрологічних захворюваннях. Результати цих досліджень можуть бути корисними для практичної ветеринарної медицини дрібних домашніх тварин.

\section{Бібліографічні посилання}

Chandler, Je.A., Gaskell, K.D., Gaskell, R.M.(2002). Bolezni koshek. M.: Akvarium LTD (in Russian).

Aljaev, Ju.G., Amosov, A.V., Androsova, S.O. [i dr.]. (2000). Nefrologija: Rukovodstvo dlja vrachej. M.: Medicina (in Russian).

Jushhenko, A.A. (2005). Mochekamennaja bolezn' domashnih koshek: patogenez, diagnostika ta lechenie: diss.... kand. vet. nauk: spec. 16.00.01. «Diagnostika i terapija zhivotnyh». Belaja Cerkov'. 20 (in Ukrainian).

Jushhenko, A.A., Timoshenko, O.P., Kibkalo, D.V. (2005). Ispol'zovanie sulodeksida dlja lechenija mochekamennoj bolezni domashnih koshek. Vestnik Belocerkovskogo gosudarstvennogo agrarnogo un-ta. Belaja Cerkov'. 31, 117-129 (in Ukrainian).

Worcester, E.M. (1996). Inhibitors of stone formation. Seminar Nephrology. 16 (5), 474-486.

Gunn-Moore, D.A., Shenoy, C.M. (2004). Oral glucosamine and the management of feline idiopathic cystitis. J. Feline Med. Surg. 6 (4), 219-225.

Morozenko, D.V., Tymoshenko, O.P. (2012). Doslidzhennja sechi sobak i kotiv $u$ diagnostyci vnutrishnih hvorob. PPV «Nove slovo». (in Ukrainian).

Стаття надійшла до редакції 11.09.2016 